CLINICAL STUDY

\title{
Effect of exogenous glucocorticoid on osmotically stimulated antidiuretic hormone secretion and on water reabsorption in man
}

\author{
Volker Bähr ${ }^{1}$, Norma Franzen ${ }^{1}$, Wolfgang Oelkers ${ }^{2}$, Andreas F H Pfeiffer ${ }^{1}$ and Sven Diederich ${ }^{1,2}$ \\ ${ }^{1}$ Department of Endocrinology, Diabetes and Nutrition, Charite-Universitatsmedizin Berlin, Campus Benjamin Franklin, Hindenburgdamm 30,12200 \\ Berlin, Germany and ${ }^{2}$ Endokrinologikum Berlin, Centre for Endocrine and Metabolic Diseases, Berlin, Germany \\ (Correspondence should be addressed to V Bähr; Email: volker.baehr@charite.de)
}

\begin{abstract}
Objective: Glucocorticoids exert tonic suppression of antidiuretic hormone (ADH) secretion. Hypocortisolism in secondary adrenocortical insufficiency can result in a clinical picture similar to the syndrome of inappropriate $\mathrm{ADH}$ secretion. On the other hand, in vitro and in vivo results provide evidence for $\mathrm{ADH}$ suppression in states of hypercortisolism. To test the hypothesis that $\mathrm{ADH}$ suppression is of relevance during glucocorticoid therapy, we investigated the influence of prednisolone on the osmotic stimulation of ADH.

Design and methods: Seven healthy men were subjected to water deprivation tests with the measurement of plasma $\mathrm{ADH}(\mathrm{pADH})$ and osmolality (posmol) before and after glucocorticoid treatment ( 5 days $30 \mathrm{mg}$ prednisolone per day).

Results: Before glucocorticoid treatment, the volunteers showed a normal test with an adequate increase of $\mathrm{pADH}$ (basal $0.54 \pm 0.2$ to $1.9 \pm 0.72 \mathrm{pg} / \mathrm{ml}$ (mean \pm s.D.)) in relation to posmol(basal $283.3 \pm 8.5$ to $293.7 \pm 6 \mathrm{mosmol} / \mathrm{kg})$. After prednisolone intake, $\mathrm{pADH}$ was attenuated $(<0.4 \mathrm{pg} / \mathrm{ml})$ in spite of an increase of posmol from $289.3 \pm 3.6$ to $297.0 \pm 5.5 \mathrm{mosmol} / \mathrm{kg}$. However, urine osmolar concentration increased normally during water deprivation after prednisolone. Urinary cAMP excretion increased during water deprivation without glucocorticoid treatment from $3.56 \pm 0.55$ to $6.07 \pm 0.76 \mu \mathrm{mol} / \mathrm{l}$, reflecting the increased pADH levels. The rise in cAMP excretion was completely blunted by prednisolone treatment.

Conclusions: We speculate that there may be an $\mathrm{ADH}$-independent stimulation of the formation or function of aquaporin-2 channels by prednisolone and/or a direct osmotic stimulation of water reabsorption independent of $\mathrm{ADH}$ and glucocorticoid control.
\end{abstract}

European Journal of Endocrinology 155 845-848

\section{Introduction}

The concentration of cortisol is controlled on multiple levels: The major stimulus for its synthesis in the adrenal is adrenocorticotropic hormone (ACTH). Synthesis and secretion of this stimulus are controlled by corticotropin-releasing hormone $(\mathrm{CRH})$ and antidiuretic hormone (ADH), also called arginine vasopressin. $\mathrm{CRH}$ and $\mathrm{ADH}$ are synthesized by neuroendocrine neurons in the medial parvocellular $(\mathrm{mp})$ part of the paraventricular nucleus of the hypothalamus and released by terminals of the neuroendocrine neurons in the median eminence into the hypophysial portal vasculature. In the anterior lobe of the pituitary gland, $\mathrm{CRH}$ and $\mathrm{ADH}$ stimulate synthesis and secretion of ACTH. In this traditional scheme, glucocorticoids, as the end-organ hormones, act as a negative feedback signal to inhibit the activity of the control elements, the corticotropes in the pituitary, and the neuroendocrine neurons in the hypothalamus. $\mathrm{ADH}$ derived from the magnocellular neurosecretory cells of supraoptic and paraventricular nuclei is transferred to the posterior pituitary gland where it is secreted in response to osmolar and non-osmolar stimuli. ADH in the peripheral circulation regulates the water permeability of renal collecting ducts via aquaporin-2 channels. A decrease in plasma osmolality centrally inhibits $\mathrm{ADH}$ secretion. Thus, ADH is involved in two more or less independent feedback loops.

On the other hand, there is evidence that these two control loops influence one another: Osmotically stimulated endogenous ADH enhances $\mathrm{CRH}$-stimulated ACTH and cortisol secretion in men $(1,2)$ and corticosterone secretion in rats (3). Some patients with hyponatremia have hypopituitarism with adrenal insufficiency. These patients have an inappropriately high ADH secretion (SIADH) and can be treated very effectively with cortisol replacement $(4,5)$. 
Exogenous cortisol (6) and dexamethasone (7) attenuate osmotically stimulated $\mathrm{ADH}$ secretion in dogs. Dogs with hyperadrenocorticism had polyuria and an impairment of osmoregulation of ADH secretion (8). In the present study, we evaluate the effect of an exogenous glucocorticoid on osmotically stimulated $\mathrm{ADH}$ secretion and on the antidiuretic action of ADH.

\section{Subjects and methods}

Seven male volunteers gave written informed consent to take part in this study, which was approved by the ethical committee of the Charite Berlin. Their age was in the range of 24-37 (average 27.7) years. No volunteer was hypertensive, had diabetes mellitus, renal insufficiency, polyuria, adiposity, hyperlipidemia, osteoporosis, or a history of peptic ulcer.

Fluid deprivation tests were performed between 0800 and $1700 \mathrm{~h}$. There was no food restriction except for soups and food containing much water, like fruits. Every $2 \mathrm{~h}$, blood samples were taken and urine was collected in the same intervals. Ammonium heparinate plasma for the determination of $\mathrm{ADH}$ was obtained within $20 \mathrm{~min}$ after sampling and stored at $-80{ }^{\circ} \mathrm{C}$, urine samples at $-20{ }^{\circ} \mathrm{C}$. After blood and urine sampling at 1600 h, $4 \mu \mathrm{g}$ V2-receptor-agonist desmopressin acetate (Minirin, Ferring Kiel, Germany) were given intravenously. At $1700 \mathrm{~h}$, the last blood and urine samples were taken (9). Two days after these basal fluid deprivation tests, the volunteers started taking $30 \mathrm{mg}$ prednisolone (Decortin H, Hoechst AG, Frankfurt, Germany) orally at $0800 \mathrm{~h}$ for the following 4 days. The fluid deprivation tests were repeated on the first and the fifth days of prednisolone intake.

Plasma and urinary osmolality was measured with an osmometer from Roebling, Berlin, Germany. Plasma $\mathrm{ADH}$ was measured using the method of Morton et al. (10). There was no crossreactivity with prednisolone (500 ng/ml, maximum concentration obtainable with $30 \mathrm{mg} /$ day).

Cyclic adenosine monophosphate (cAMP) in urine was determined using a $\left[{ }^{3} \mathrm{H}\right]$-cAMP radioimmunoassay (Amersham International).

\section{Results}

The volunteers showed a normal response to fluid deprivation. The rise in plasma osmolality after $8 \mathrm{~h}$ thirsting (from $283.3 \pm 8.5$ to $293.7 \pm 6 \mathrm{mosmol} / \mathrm{kg}$ (mean \pm s.D. $)$ ) was accompanied by an appropriate rise in $\mathrm{ADH}$ plasma concentration $(0.54 \pm 0.2$ to $1.9 \pm 0.72 \mathrm{pg} / \mathrm{ml}$; Fig. 1). The normal range was defined based on Robertson et al. (11) and our own previous investigations (9). The intake of $30 \mathrm{mg}$ prednisolone per day resulted in a suppression of

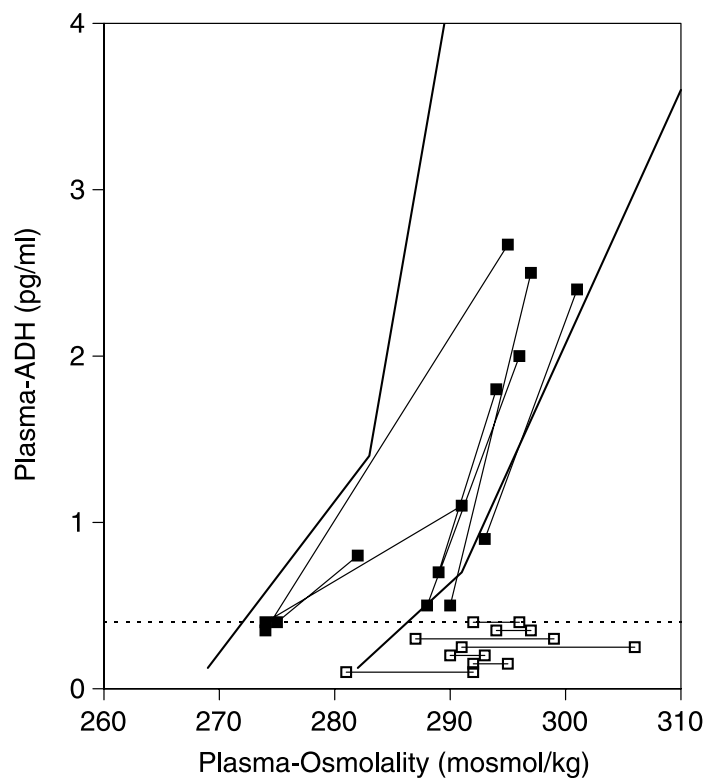

Figure 1 Plasma antidiuretic hormone (ADH) concentration and plasma osmolality in fluid deprivation tests in men at the fifth day of prednisolone treatment $(\square)$ and without glucocorticoid treatment (ם). Normal range and detection limit of $\mathrm{ADH}$ indicated by solid and broken lines.

plasma ADH below $0.4 \mathrm{pg} / \mathrm{ml}$ (below the sensitivity of the radioimmunoassay). Figure 1 combines the results of the fluid deprivation test at the fifth day of prednisolone intake. Plasma osmolality at the first day of prednisolone intake rose from $289.3 \pm 3.6$ to $297 \pm 5.5 \mathrm{mosmol} / \mathrm{kg}$ after $8 \mathrm{~h}$ thirsting and at the fifth day of prednisolone from $289 \pm 4.4$ to $296 \pm$ $4.7 \mathrm{mosmol} / \mathrm{kg}$. There were no differences in blood sugar values before and after treatment with prednisolone.

Prior to the days of prednisolone intake related to the rise in plasma osmolality, there was a rise in urine osmolality from $664.6 \pm 222.0$ to $1037.3 \pm$ $75.5 \mathrm{mosmol} / \mathrm{kg}$ after $8 \mathrm{~h}$ thirsting. Although plasma $\mathrm{ADH}$ was below $0.4 \mathrm{pg} / \mathrm{ml}$ at the first and the fifth day of prednisolone intake, urine osmolality rose after thirsting from $727.4 \pm 223.3$ to $1061.1 \pm 127.0$ and from $650.3 \pm 278.6$ to $1041 \pm 182.8 \mathrm{mosmol} / \mathrm{kg}$ respectively. Thus, all volunteers were able to concentrate their urine after thirsting at the first and the fifth day of prednisolone intake although plasma $\mathrm{ADH}$ was below $0.4 \mathrm{pg} / \mathrm{ml}$ (Fig. 2).

Urinary cAMP reflected the dynamic of plasma ADH. Without prednisolone intake, urinary cAMP was stimulated from $3.56 \pm 0.55$ to $6.07 \pm 0.76 \mu \mathrm{mol} / \mathrm{l}$ after thirsting and after i.v. injection of desmopressin acetate to $9.57 \pm 1.43 \mu \mathrm{mol} / \mathrm{l}$. At the fifth day of prednisolone intake, thirsting did not induce a rise in urinary cAMP (from $4.6 \pm 1.02$ to $4.28 \pm 0.49$ ) but desmopressin acetate induced a rise to $5.95 \pm$ $0.59 \mu \mathrm{mol} / \mathrm{l}(P<0.05)$. 


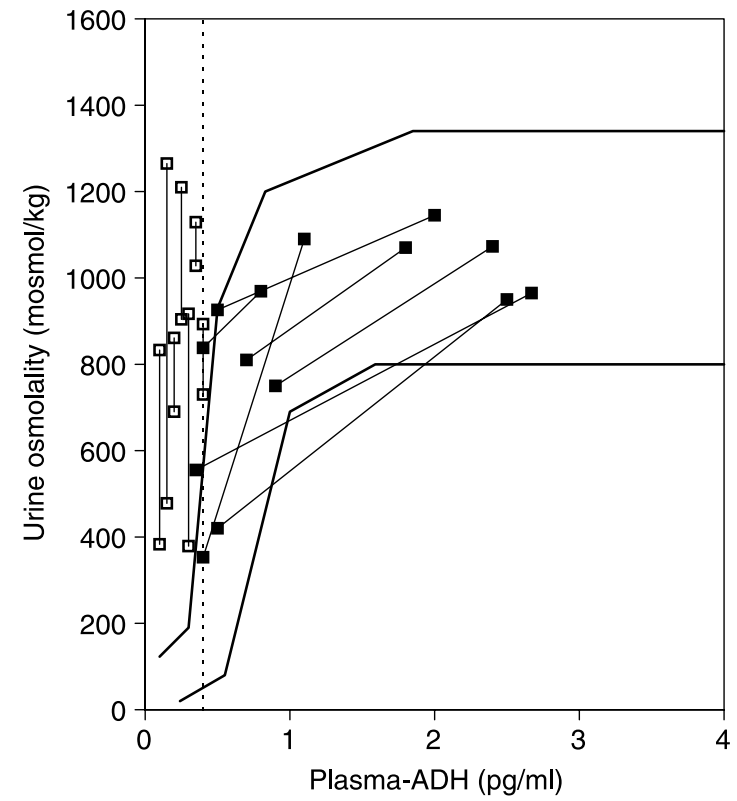

Figure 2 Urine osmolality and plasma antidiuretic hormone (ADH) concentration in fluid deprivation tests in men at the fifth day of prednisolone treatment $(\square)$ and without glucocorticoid treatment (西).Normal range and detection limit of ADH indicated by solid and broken lines.

\section{Discussion}

In this study, prednisolone markedly inhibited osmotically stimulated ADH secretion in healthy subjects. Although it remains to be proven that prednisolone intake does not decrease the half-life of $\mathrm{ADH}$, this may be rather unlikely because, due to the sensitivity of the assay, the half-life would have to be shortened to oneeighth to explain the results. Five days of prednisolone intake did not induce a rise in plasma glucose. Therefore, the osmotic stimuli induced by water deprivation may be comparable. The inhibition of osmotically stimulated ADH secretion by prednisolone may support the concept of glucocorticoid control of ADH secretion into the circulation. Glucocorticoids appear to inhibit ADH secretion physiologically in a tonic way, and thereby prevent ADH hypersecretion and dilutional hyponatremia in stressful situations $(4,5)$. Cortisol (6) and dexamethasone (7) also inhibit ADH secretion in dogs. Some patients (10-15\%) with Cushing's syndrome are polyuric and polydipsic (12, 13). This may be related to suppression of ADH secretion by cortisol, although in our study the suppression of ADH by prednisolone was not accompanied by impaired urine concentrating ability of the kidney. Cortisol and ADH form two overlapping feedback loops. First, ADH synthesized in the parvocellular neurons of the hypothalamus (nuclei paraventricularis) is released into the pituitary portal system at the median eminence. It stimulates corticotropin release in cooperation with CRH. Corticotropin stimulates cortisol, which feeds back on hypothalamic ADH synthesis and release. Second, ADH synthesized in the magnocellular neurons of the supraoptic and paraventricular nuclei travels along nerve projections into the neurohypophysis, where it is released into the circulation in response to osmotic and non-osmotic (e.g. hypovolemia) stimuli. Circulating ADH acts on the kidney in order to decrease plasma osmolality. While variations in plasma cortisol lead to suppression or de-repression of $\mathrm{ADH}$ secretion into the peripheral circulation $(6,7,12,13)$, osmotic stimuli may also influence the feedback loop between ADH, corticotropin and cortisol (1-3).

As far as we are aware, suppression of ADH secretion into the circulation by glucocorticoids without impairment of the renal concentrating ability has not been described previously. In the dog, suppression of plasma ADH by cortisol infusion also impaired the increase in urine osmolality in response to the infusion of hypertonic saline (6). A functional correlate of $\mathrm{ADH}$ suppression in our study is the failure of urinary cAMP output to respond to water deprivation. Exogenous desmopressin led to a small increase in urinary cAMP, but the effect of cAMP was blunted in comparison with the studies before prednisolone administration.

There are several lines of evidence that ADH may be the most important regulator of plasma osmolality via aquaporin-2 (AQP2) water channels but not the only one. Brattleboro rats that do not express ADH up-regulate $\mathrm{AQP} 2$ in response to osmotic stimulation (14). Dehydration reverses vasopressin antagonistinduced diuresis and AQP2 down-regulation in Wistar rats, although an effective receptor blockade was confirmed by control experiments (15). In men, water loading lowered AQP2 urinary excretion but water loading and additional ibuprofen intake enhanced the secretion of this protein (16).

The mechanism(s) that would explain a vasopressinindependent regulation of AQP2 are not well understood. The adenylate cyclase-coupled vasopressin receptor activates the AQP2 promoter via a dual effect on CRE and AP-1 elements $(17,18)$. In addition, vasopressin stimulates phosphorylation of AQP2 at $\mathrm{Ser}^{256}$ and its trafficking to the plasma membrane. In primary cultured inner medulIary collecting duct cells, angiotensin II stimulates AQP2 expression and plasma membrane insertion probably via stimulation of PKA activity (19). The renal adenylate cyclase activity is also stimulated by $\beta$-adrenergic stimuli (20) and prostacyclin (21). The AQP2 promoter is also activated by the tonicity-responsive enhancer binding protein, whose activity is enhanced in collecting duct principal cells by hypertonic challenge (22). The insertion into plasma membrane is not stimulated by hypertonicity (23).

In rat cultured renal papillary collecting tubule cells PKA was stimulated by prostaglandin E2 (PGE2) (24). The phosphorylation of AQP2 at $\operatorname{Ser}^{256}$ is not influenced by PGE2 in rat renal inner medulla cells, 
but the translocation of AQP2to the membrane is inhibited, the ratio of membrane-enriched AQP2 to vesicle-enriched AQP2 in vasopressin-stimulated cells is suppressed to control values by prostaglandin E2 (25). This is compatible with the above-mentioned stimulation of urinary AQP2 excretion in men induced by PGE2 synthesis inhibition by ibuprofen (16). This action may be related to the action of prednisolone in this study. Glucocorticoids are also known to inhibit PGE2 synthesis $(26,27)$ and it may be possible that they stimulate AQP2 excretion by this mechanism.

In summary, we have shown that supraphysiological glucocorticoid levels totally suppress osmotically stimulated $\mathrm{ADH}$ secretion. Therefore, water deprivation tests are highly affected by exogenous glucocorticoids. This should be considered in clinical differential diagnoses of the polyuria-polydipsia syndrome. On the other hand, urinary concentration ability in healthy young men was not influenced in spite of low ADH levels. In order to explain this observation further, in vitro and in vivo investigations are necessary.

\section{References}

1 Milsom SR, Conaglen JV, Donald RA, Espiner EA, Nicholls MG \& Livesey JH. Augmentation of the response to CRF in man: relative contributions of endogenous angiotensin and vasopressin. Clinical Endocrinology 198522 623-629.

2 Bähr V, Hensen J, Hader O \& Oelkers W. Effects of osmotically stimulated endogenous vasopressin on basal and CRH-stimulated ACTH release in man. Acta Endocrinologica 1988117 103-108.

3 Graf MV, Kastin AJ \& Fischman AJ. Interaction of arginine vasopressin and corticotropin releasing factor demonstrated with an improved bioassay. Proceedings of the Society for Experimental Biology and Medicine 1985179 303-308.

4 Oelkers W. Hyponatremia and inappropriate secretion of vasopressin (antidiuretic hormone) in patients with hypopituitarism (see comments). New England Journal of Medicine 1989 $321492-496$.

5 Diederich S, Franzen NF, Bähr V \& Oelkers W. Severe hyponatremia due to hypopituitarism with adrenal insufficiency: report on 28 cases. European Journal of Endocrinology 2003148 609-617.

6 Papanek PE \& Raff H. Chronic physiological increases in cortisol inhibit the vasopressin response to hypertonicity in conscious dogs. American Journal of Physiology 1994267 R1342-R1349.

7 Raff H, Skelton MM \& Cowley AW Jr. Feedback control of vasopressin and corticotrophin secretion in conscious dogs: effect of hypertonic saline. Journal of Endocrinology 1989 122 41-48.

8 Biewenga WJ, Rijnberk A \& Mol JA. Osmoregulation of systemic vasopressin release during long-term glucocorticoid excess: a study in dogs with hyperadrenocorticism. Acta Endocrinologica $1991124583-588$.

9 Diederich S, Eckmanns T, Exner P, Al Saadi N, Bähr V \& Oelkers W. Differential diagnosis of polyuric/polydipsic syndromes with the aid of urinary vasopressin measurement in adults. Clinical Endocrinology $2001 \mathbf{5 4}$ 665-671.

10 Morton JJ, Connell JM, Hughes MJ, Inglis GC \& Wallace EC. The role of plasma osmolality, angiotensin II and dopamine in vasopressin release in man. Clinical Endocrinology 198523 $129-138$.
11 Robertson GL \& Ganguly A. Osmoregulation and baroregulation of plasma vasopressin in essential hypertension. Journal of Cardiovascular Pharmacology 19868 (Suppl 7) S87-S91.

12 Boscaro M, Barzon L, Fallo F \& Sonino N. Cushing's syndrome. Lancet 2001357 783-791.

13 Allolio B. In Praktische Endokrinologie, pp 219-227. Ed. B Allolio, München, Wien, Baltimore: Urban und Schwarzenberg, 2006.

$14 \mathrm{Li} \mathrm{C}$, Wang W, Summer SN, Cadnapaphornchai MA, Falk S, Umenishi F \& Schrier RW. Hyperosmolality in vivo upregulates aquaporin 2 Water channel and $\mathrm{Na}-\mathrm{K}-2 \mathrm{Cl}$ co-transporter in brattleboro rats. Journal of the American Society of Nephrology 2006 17 1657-1664.

15 Marples D, Christensen BM, Frokiaer J, Knepper MA \& Nielsen S. Dehydration reverses vasopressin antagonist-induced diuresis and aquaporin-2 downregulation in rats. American Journal of Physiology 1998275 F400-F409.

16 Pedersen RS, Bentzen H, Bech JN \& Pedersen EB. Effect of an acute oral ibuprofen intake on urinary aquaporin- 2 excretion in healthy humans. Scandinavian Journal of Clinical and Laboratory Investigation $200161631-640$.

17 Matsumura Y, Uchida S, Rai T, Sasaki S \& Marumo F. Transcriptional regulation of aquaporin-2 water channel gene by cAMP. Journal of the American Society of Nephrology $1997 \mathbf{8}$ 861-867.

18 Yasui M. Zelenin SM. Celsi G \& Aperia A. Adenylate cyclasecoupled vasopressin receptor activates AQP2 promoter via a dual effect on CRE and AP1 elements. American Journal of Physiology. Renal Physiology 1997272 F443-F450.

19 Lee YJ, Song IK, Jang KJ, Nielsen J, Frokiaer J, Nielsen S \& Kwon TH. Increased AQP2 targeting in primary cultured IMCD cells in response to angiotensin II through AT1 receptor. Renal Physiology 2006 [epub ahead of print].

20 Teitelbaum I, Strasheim A \& Berl T. Adrenergic control of cAMP generation in rat inner medullary collecting tubule cells. Kidney International 198935 647-653.

21 Veis JH. Dillingham MA \& Berl T. Effects of prostacyclin on the cAMP system in cultured rat inner medullary collecting duct cells. American Journal of Physiology. Renal Physiology 1990258 F1218-F1223.

22 Hasler U, Jeon US, Kim JA, Mordasini D, Kwon HM, Feraille E \& Martin PY. Tonicity-responsive enhancer binding protein is an essential regulator of aquaporin-2 expression in renal collecting duct principal cells. Journal of the American Society of Nephrology 200617 1521-1531.

23 Storm R, Klussmann E, Geelhaar A, Rosenthal W \& Maric K. Osmolality and solute composition are strong regulators of AQP2 expression in renal principal cells. American Journal of Physiology. Renal Physiology 2003284 F189-F198.

24 Sato M \& Dunn MJ. Interactions of vasopressin, prostaglandins, and cAMP in rat renal papillary collecting tubule cells in culture. American Journal of Physiology. Renal Physiology 1984 247 F423-F433.

25 Zelenina M, Christensen BM, Palmer J, Nairn AC, Nielsen S \& Aperia A. Prostaglandin E(2) interaction with AVP: effects on AQP2 phosphorylation and distribution. American Journal of Physiology. Renal Physiology 2000278 F388-F394.

26 Turesin F, del SP \& Wallace JL. Enhanced anti-inflammatory potency of a nitric oxide-releasing prednisolone derivative in the rat. British Journal of Pharmacology 2003139 966-972.

27 Goppelt-Struebe M. Molecular mechanisms involved in the regulation of prostaglandin biosynthesis by glucocorticoids. Biochemical Pharmacology 199753 1389-1395.

Received 19 June 2006

Accepted 18 September 2006 